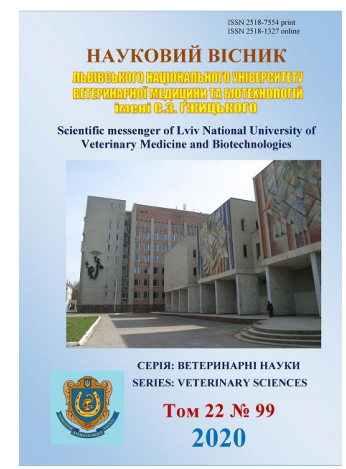

Науковий вісник Дьвівського національного університету ветеринарної медицини та біотехнодогій імені С.3. Гжицького. Серія: Ветеринарні науки

\author{
Scientific Messenger of Lviv National University \\ of Veterinary Medicine and Biotechnologies. \\ Series: Veterinary sciences
}

\title{
Pharmaco-toxicological properties of the drug "Ciflur" as a preventive agent for nodular dermatitis
}

\author{
A. B. Berezovsky, T. I. Fotina, A. J. Ragatova, P. G. Bondarenko, L. V. Nagorna, S. M. Nazarenko \\ Sumy National Agrarian University, Sumy, Ukraine
}

Article info

Received 10.09.2020

Received in revised form 12.10 .2020

Accepted 13.10.2020

Sumy National

Agrarian University,

Gerasim Kondratiev Str., 160,

Sumy, 40000, Ukraine.

Tel.: +38-095-495-29-33

E-mail: tif ua@meta.ua
Berezovsky, A. B., Fotina, T. I., Ragatova, A. J., Bondarenko, P. G., Nagorna, L. V., \& Nazarenko, S. M. (2020). Pharmaco-toxicological properties of the drug "Ciflur" as a preventive agent for nodular dermatitis. Scientific Messenger of Lviv National University of Veterinary Medicine and Biotechnologies. Series: Veterinary sciences, 22(99), 116-119. doi: 10.32718/nvlvet9918

The article presents data study of acute toxicity of the drug "Ciflur". Nodular dermatitis causes significant economic losses due to a temporary decrease in milk productivity, temporary or permanent sterility of breeding bulls, skin lesions, and death of sick animals due to secondary infections. Specific treatments have not been developed. Preventive disinsection of livestock premises is effective for prevention. For this purpose, a new drug "Ciflur" was developed. $1 \mathrm{ml}$ of the drug contains the active substance: cyfluthrin - $10.0 \mathrm{mg}$. Toxicity studies of the drug and evaluation of the results were performed in accordance with standard methods. The study of acute toxicity of the drug "Ciflur" when applied to the skin was performed on 18 white rats weighing 170-190 g. The animals were divided into 3 groups of 6 heads. Rats were kept in the vivarium in accordance with sanitary rules and on a standard diet adopted in the vivarium with the use of compound feed. The first group of rats on the skin was applied the drug "Ciflur" at a dose of $1250 \mathrm{mg} / \mathrm{kg}$, the second - $2500 \mathrm{mg} / \mathrm{kg}$ body weight. The third group of rats was a control - these animals on the skin was applied Solveso 200 solvent in the amount of $2500 \mathrm{mg} / \mathrm{kg}$ body weight. Acute toxicity of the drug was studied when applying the drug to a pre-cut area of skin on the back, which was at least $10 \%$ of the total surface area of the animal. In order to prevent excessive spreading on the skin, the drug was applied slowly, drying with warm air with a hair dryer. For 14 days after cutaneous application of the drug was recorded daily its effect on the survival of rats, the appearance of rats and manifestations of physiological disorders of animals. Rats were weighed before application, as well as 3, 7 and 14 days after the start of the study. After 14 days, an autopsy was performed and the condition of the internal organs was examined for possible impressions, and the internal organs were weighed and their relative weight coefficients were calculated. Therefore, a single skin application of "Ciflur" at doses of 1250 and $2500 \mathrm{mg} / \mathrm{kg}$ body weight did not result in the death of experimental rats. The acute LD50 of the drug "Ciflur" when applied to the skin exceeds $2500 \mathrm{mg} / \mathrm{kg}$ body weight, which allows it to be classified as hazard class 4 according to the International Standard GOST 12.1.007-76, or category 5 according to the International Global Classification of Harmonized System (GHS). Only the application of "Ciflur" at the highest dose $(2500 \mathrm{mg} / \mathrm{kg}$ body weight) caused a slight short-term reddening of the skin in some experimental rats, which disappeared without intervention for 4-8 hours.

Key words: acute toxicity, "Ciflur", rats, infectious disease, disinsection.

\section{Фармако-токсикологічні властивості препарату “Цифлур" як профілактичного засобу за нодулярного дерматиту}

А. В. Березовський, Т. І. Фотіна, А. Ж. Рогатова, П. Г. Бондаренко, Л. В. Нагорна, С. М. Назаренко

Сумський начіональний аграрний університет, м. Суми, Украӥна 
У статті наведені дані щзодо вивчення фармако-токсикологічних властивостей препарату “Цифлур” як профілактичного засобу за нодулярного дерматиту. Нодулярний дерматит спричиняє значні економічні втрати через те, ияо викликає тимчасове зниження молочної продуктивності, тимчасову або постійну стерильність биків-плідників, ураження шкіри, а також загибель хворих тварин унаслідок секундарних інфекиій. Специфічні методи лікування не розроблені. Для профілактики ефективним є дезінсекиія тваринницьких приміщень. 3 иією метою було розроблено новий препарат “Цифлур”. 1 мл препарату містить діючу речовину: иифлутрин - 10,0 мг. Дослідження токсичності препарату та оцінку отриманих результатів проводили відповідно до стандартних методів. Вивчення гострої токсичності препарату “Цифлур” при нашкірному нанесенні проводили на 18 білих шурах масою тіла 170-190 г. Тварин розділяли на 3 групи по 6 голів. Щурів утримували у віварії згідно з санітарними правилами та на стандартному раціоні, прийнятими у віварї з використанням комбікорму. Першій групі шурів на шкіру наносили препарат “Цифлур” в дозі 1250 мг/кг, другій - 2500 мг/кг маси тіла. Третя група шурів була контрольною - цим тваринам на шкіру наносили розчинник Сольвессо 200 в кількості 2500 мг/кг маси тіла. Гостру токсичність препарату вивчали при нанесенні препарату на попередньо вистрижену ділянку шкіри на спині, яка становила не менше ніж 10 \% від загальної площі поверхні тварини. 3 метою запобігання надмірному розтіканню по шкірі препарат наносили повільно, підсушуючи теплим повітрям за допомогою фена. Впродовж 14 діб після нашкірного нанесення препарату щуоденно реєстрували його вплив на виживання шурів, на зовнішній вигляд щурів і прояви порушень фізіологічного стану тварин. Щурів зважували до нанесення препарату, а також через 3 , 7 та 14 діб від початку досліджень. Через 14 діб проводили розтин та обстеження внутрішніх органів на наявність можливих уражень, внутрішні органи зважували та розраховували коефіцієнтів їх відносної маси. Отже, одноразове нашкірне нанесення препарату “Цифлур” в дозах 1250 та 2500 мг/кг маси тіла не спричиняло загибелі піддослідних шурів. LD5о препарату “Цифлур” при нашкірному нанесенні перевищує 2500 мг/кг маси тіла, що дозволяє віднести його до 4 класу небезпеки згідно з Міжнародним стандартом ГОСТ 12.1.007-76 або до категоріі 5 за Міжнародною глобальною класифікацією Global Harmonized System, (GHS). Лише нанесення препарату “Цифлур” в найбільшій дозі (2500 мг/кг маси тіла) спричиняло незначне короткострокове почервоніння шкіри у частини піддослідних шурів, яке зникало саме без стороннього втручання впродовж 4-8 годин.

Ключові слова: гостра токсичність, “Цифлур”, щурі, інфекційне захворювання, дезінсекція.

\section{Вступ}

Нодулярний дерматит великої рогатої худоби (вузликова екзантема, заразний вузликовий дерматит, Dermatitis nodulares, Lumpy skin disease) - контагіозне інфекційне захворювання, що характеризується лихоманкою, ураженням лімфатичної системи, набряками підшкірної клітковини та внутрішніх органів, утворенням шкіряних вузлів (бугрів), ураженням очей i слизових оболонок органів дихання та травлення. Хвороба належить до особливо небезпечних хвороб великої рогатої худоби. Нодулярний дерматит спричиняє значні економічні втрати через те, що викликає тимчасове зниження молочної продуктивності, тимчасову або постійну стерильність биків-плідників, ураження шкіри, а також загибель хворих тварин унаслідок секундарних інфекцій. Специфічні методи лікування не розроблені. Хворіє велика рогата худоба, вівці, кози та жуйні дикі тварини. Хвороба включена до списку МЕБ та підлягає обов'язковій нотифікації. Збудником нодулярного дерматиту є ДНК вмісний вірус групи Neethling роду Capripoxvirus сімейства Poxviridae, що має антигенну спорідненість з вірусом віспи овець. Зрілі віріони круглої форми, мають подвійну оболонку, щільну серцевину та бокові тільця. За своєю морфологією вірус ідентичний 3 вірусом віспи (Nevolko et al., 2017; Nechyporenko et al., 2020).

3 метою профілактики ефективним є дезінсекція тваринницьких приміщень. Проводяться заходи, спрямовані на знищення стаціонарних ареалів мешкання комах - переносників збудника хвороби.

Актуальність теми. Варто зазначити, що комахи належать до категорії найбільш небезпечних біологічних агентів і $є$ найчисельнішим за видовим різноманіттям класом тварин. Завдяки своїй надзвичайній лабільності й здатності пристосовуватися до умов середовища, які швидко змінюються, популяції комах, які паразитують на продуктивних тваринах, постійно зростають (Kutsan \& Ponomarenko, 2003; Abramov et al., 2013; Nagorna, 2016). Нерідко членистоногі є ос- новними провокаційними чинниками спалахів бактеріозів та віроозів у господарствах.

Ураженню худоби сприяє заселення виробничих приміщень кровосисними комахами, до яких належать гедзі, комарі, мошки, мокриці, москіти, об'єднані під однією народною назвою - гнус. Паразитичні комахи є суттєвою проблемою для світового тваринництва, незважаючи на те, що одним із головних технологічних досягнень ветеринарної науки у XX столітті стало створення засобів широкого спектру дії проти збудників екто- та ендопаразитів тварин (Kutsan \& Ponomarenko, 2003). Сучасним рішенням даної проблематики наразі є розробка та впровадження у виробництво принципово нових інсектоакарацидів та синергічне поєднання їх діючих речовин у комбінованих препаратах. 3 цією метою було розроблено новий препарат “Цифлур”. 1 мл препарату містить діючу речовину: цифлутрин - 10,0 мг.

Метою досліджень було вивчення фармакотоксикологічних властивостей препарату "Цифлур" як профілактичного засобу за нодулярного дерматиту.

\section{Матеріал і методи досліджень}

Дослідження фармако-токсикологічних досліджень препарату "Цифлур" та оцінку отриманих результатів проводили відповідно до методів викладених в матеріалах (Kosenko et al., 1997; Kotsiumbas et al., 2006) на кафедрі ветсанекспертизи, мікробіології, зоогігієни та безпеки і якості продуктів тваринництва Сумського національного аграрного університету.

Вивчення токсичності препарату “Цифлур" при нашкірному нанесенні проводили на 18 білих щурах масою тіла 170-190 г. Тварин розділяли на 3 групи по 6 голів. Щурів утримували у віварії згідно з санітарними правилами та на стандартному раціоні, прийнятими у віварії з використанням комбікорму.

Першій групі щурів на шкіру наносили препарат “Цифлур” в дозі 1250 мг/кг, другій - 2500 мг/кг маси тіла. Третя група щурів була контрольною - цим тва- 
ринам на шкіру наносили розчинник Сольвессо 200 в кількості 2500 мг/кг маси тіла. Токсичність препарату вивчали при нанесенні препарату на попередньо вистрижену ділянку шкіри на спині, яка становила не менше ніж 10 \% від загальної площі поверхні тварини. 3 метою недопущення надмірного розтікання по шкірі препарат наносили повільно, підсушуючи теплим повітрям за допомогою фену.

Впродовж 14 діб після нашкірного нанесення препарату щоденно реєстрували його вплив на виживання щурів, на зовнішній вигляд щурів і прояви порушень фізіологічного стану тварин. Щурів зважували до нанесення препарату, а також через 3, 7 та 14 діб від початку досліджень. Через 14 діб проводили розтин тварин та обстеження стану внутрішніх органів на наявність можливих вражень, внутрішні органи зважували та розраховували коефіцієнти їх відносної маси.

\section{Таблиця 1}

Динаміка зміни маси тіла щурів $(\mathrm{M} \pm \mathrm{m})$ після нашкірного нанесення препарату “Цифлур” $(\mathrm{n}=6)$

\begin{tabular}{ccccc}
\hline \multirow{2}{*}{$\begin{array}{c}\text { Доза препарату “Цифлур”, } \\
\text { нанесена на шкіру (мг/кг) }\end{array}$} & \multicolumn{4}{c}{ Маса тіла щурів (г) при зважуванні через (діб з початку досліджень) } \\
\cline { 2 - 5 } & До початку & 3 & 7 & 14 \\
\hline 1250 & $174,0 \pm 8,2$ & $187,3 \pm 9,4$ & $194,0 \pm 5,5$ & $201,8 \pm 11,0$ \\
2500 & $171,5 \pm 7,6$ & $182,7 \pm 7,2$ & $192,0 \pm 6,5$ & $202,1 \pm 10,1$ \\
Контрольна група & $181,3 \pm 8,6$ & $192,0 \pm 6,1$ & $198,7 \pm 5,2$ & $202,0 \pm 9,3$ \\
\hline
\end{tabular}

При розтині тварин не спостерігали видимих патологічних змін у внутрішніх органах та тканинах щурів. Також не реєстрували достовірних змін відносних масових коефіцієнтів внутрішніх органів щурів до маси тіла щурів, які визначали в кінці дослідження (табл. 2).

В результаті проведених досліджень встановлено, що одноразове нашкірне нанесення препарату "Цифлур" в дозах 1250 та 2500 мг/кг маси тіла не

\section{Результати та їх обговорення}

Результати проведених досліджень показали, що одноразове нанесення препарату “Цифлур” на шкіру щурам в доза 1250 та 2500 мг/кг маси тіла не спричиняло загибелі піддослідних тварин. Із усіх змін, які реєстрували, було лише незначне почервоніння шкіри у трьох із шести піддослідних тварин, яким наносили препарат "Цифлур" в дозі 2500 мг/кг маси тіла, що саме щезало впродовж 4-8 годин без стороннього втручання.

Динаміка зміни маси тіла тварин, яким на шкіру наносили препарат “Цифлур”, за цими показниками не відрізнялися від показників контрольної групи тварин та не відрізнялись між собою (таблиця 1). спричиняло загибелі піддослідних щурів. Таким чином, LD 50 гостра препарату “Цифлур” при нашкірному нанесенні лежить за межами та перевищує 2500 мг/кг маси тіла, що дозволяє віднести його до 4 класу небезпеки згідно з Міжнародним стандартом ГОСТ 12.1.007-76 (GOST 12.1.007-76) або до категорії 5 за Міжнародною глобальною класифікацією Global Harmonized System, (GHS).

\section{Таблиця 2}

Масові коефіцієнти внутрішніх органів забитих піддослідних щурів ( \pm m) після нашкірного нанесення препарату “Цифлур”

\begin{tabular}{lrrr}
\hline \multirow{2}{*}{ Внутрішні органи } & \multicolumn{3}{c}{ Доза препарату “Цифлур” (мг/кг маси тіла) } \\
\cline { 2 - 4 } & \multicolumn{1}{c}{ Печінка } & \multicolumn{1}{c}{2500} & Контрольна група \\
Легені & $10,1 \pm 0,05$ & $9,9 \pm 0,05$ & $10,2 \pm 0,06$ \\
Серце & $1,8 \pm 0,02$ & $1,9 \pm 0,02$ & $1,9 \pm 0,03$ \\
Нирки & $0,91 \pm 0,09$ & $0,89 \pm 0,09$ & $0,93 \pm 0,05$ \\
Селезінка & $1,68 \pm 0,06$ & $1,65 \pm 0,06$ & $1,66 \pm 0,08$ \\
& $1,30 \pm 0,08$ & $1,32 \pm 0,08$ & $1,32 \pm 0,06$ \\
\hline
\end{tabular}

Лише нанесення препарату “Цифлур” в найбільшій дозі (2500 мг/кг маси тіла) спричиняло незначне короткострокове почервоніння шкіри у частини піддослідних щурів, яке зникало саме без стороннього втручання впродовж 4-8 годин.

\section{Висновки}

1. Одноразове нашкірне нанесення препарату "Цифлур" в дозах 1250 та 2500 мг/кг маси тіла не спричиняло загибелі піддослідних щурів. $\mathrm{LD}_{50}$ препа-

рату “Цифлур” при нашкірному нанесенні перевищує 2500 мг/кг маси тіла, що дозволяє зарахувати його до 4 класу небезпеки згідно з Міжнародним стандартом ГОСТ 12.1.007-76 або до категорії 5 за Міжнародною глобальною класифікацією Global Harmonized System, (GHS).

2. Лише нанесення препарату “Цифлур” в найбільшій дозі (2500 мг/кг маси тіла) спричиняло незначне короткострокове почервоніння шкіри у частини піддослідних щурів, яке зникало саме без стороннього втручання впродовж 4-8 годин. 
Перспективи подальших досліджень. У подальшому планується вивчити особливості застосування препарату “Цифлур” за профілактики нодулярного дерматиту великої рогатої худоби.

\section{References}

Abramov, V. E., Kvichko, L. I., Arhipov, I. A., Safarova, M. I., \& Birjukova, N. P. (2013). Vlijanie $1 \%$-nogo rastvora ciflutrina na reproduktivnuju funkciju belyh krys. Rossijskij parazitologicheskij zhurnal, 1, 95-97. URL: https://cyberleninka.ru/article/n/vliyanie-1-nogorastvora-tsiflutrina-na-reproduktivnuyu-funktsiyu-belyhkrys (in Russian).

GOST 12.1.007-76 (1982). SSBT. Vrednye veshhestva. Klassifikacija i obshhie trebovanija bezopasnosti. GOST 12.1.007-76. SSBT. Vved. 1977-01-01; Izmenen $\mathrm{N}$ 1; Pereizdan 01.12.81. M.: Izd-vo standartov (in Russian).

Kosenko, M. V., Malyk, O. H., \& Kotsiumbas, I. Ia. (1997). Toksykolohichnyi kontrol novykh zasobiv zakhystu tvaryn: metodychni rekomendatsii. K. (in Ukrainian).

Kotsiumbas, I. Ya., Malyk, O. H., Patereha, I. P. ta in (2006). Doklinichni doslidzhennia veterynarnykh likarskykh zasobiv. za redaktsiieiu I. Ya. Kotsiumbasa. Lviv: Triada plius (in Ukrainian).

Kutsan, O. T., \& Ponomarenko, O. V. (2003). Vyvchennia vplyvu likuvalnoho zasobu «Nuritsyd» na klinichnyi stan ta hematolohichni pokaznyky kroliv za umovy aplikatsii yoho na shkiru tvaryn. Veterynarna medytsyna: Mizh-vid. temat. nauk. Zb., 82, 343-349 (in Ukrainian).

Nagorna, L. (2016). Pharmaco-toxicological assessment preparation "Tsiflur". Scientific Messenger of LNU of Veterinary Medicine and Biotechnologies. Series: Veterinary Sciences, 18(3(71), 214-217. doi: $10.15421 /$ nvlvet7149.

Nahorna, L. V. (2016). Vyznachennia teratohennosti preparatu "Tsyflur". Problemy zooinzhenerii ta veterynarnoi medytsyny: Zb. nauk. prats KhDZVA, 33(2), 86-89. URL: http://nbuv.gov.ua/UJRN/pzvm_2016_33\%282\%29 21(in Ukrainian).

Nechyporenko, O., Berezovskyy, A., Fotina, T., \& Petrov, R. (2020). Determination of the cumulative and skinresorptive action of the Zoodizin disinfectant. Scientific Messenger of LNU of Veterinary Medicine and Biotechnologies. Series: Veterinary Sciences, 22(97), 26-30. doi: 10.32718/nvlvet9705.

Nevolko, O., Priskoka, V., Kurtiak, B., Svidersky, V., Skovpen, V., Skorokhod, S., Datsenko, R., Moroz, A., \& Garkavenko, V. (2017). Trends of infectious diseases definition of risk and forecast. Scientific Messenger of LNU of Veterinary Medicine and Biotechnologies. Series: Veterinary Sciences, 19(73), 89-94. doi: 10.15421/nvlvet7319.

Zakon Ukrainy "Pro veterynarnu medytsynu" vid 25 chervnia 1992 r. No2498-XII (zi zminamy i dopovnenniamy). URL: http://zakon.rada.gov.ua/laws/show/2498-12 (in Ukrainian). 